\title{
Does Input Substitutability in Banking Differ across Accession and Non-Accession Countries in Central and Eastern Europe?
}

\author{
Tong Wu \\ Auburn University \\ Steven B. Caudill \\ Rhodes College
}

Daniel M. Gropper

Auburn University

Valentina Hartarska

Auburn University

Franklin G. Mixon, Jr.

Columbus State University

\begin{abstract}
This study extends previous research by comparing banks across European Union (EU) accession and non-accession countries of central-eastern Europe in order to detect differences that perhaps have implications related to policy prescriptions for joining the EU. Using commercial banking data from 17 centraleastern European countries for 2000-04, the period leading up to the EU accessions of 2004 and 2007, a multiproduct translog cost function approach

\footnotetext{
*Corresponding address: Franklin G. Mixon, Jr.; D. Abbott Turner College of Business \& Computer Science, Columbus State University, 4225 University Avenue, Columbus, GA, USA. E-mail: mixon_franklin@colstate.edu

○2012-Center for Economic Integration, Sejong Institution, Sejong University, All Rights Reserved.
} 
reveals that banks in accession countries generally display stronger input substitutability across capital, labor and deposits than that displayed by banks in non-accession countries. The implication regarding the higher substitutability between capital and labor in EU accession countries is lower banking industry employment in those countries after EU accession. Bank deposits are also substitutes for labor, reflecting the substantial impact of international competition and technological advancements in the industry. As a result of these relationships, pre-accession preparation for the forthcoming banking industry changes may be necessary in some instances.

- JEL Classification: D24, F15, F36, F53, G21

- Keywords: European Union Accession, Bank Efficiency, Translog Cost Functions

\section{Introduction and Background}

In May of 2004, eight central-eastern European countries - the Czech Republic, Estonia, Hungary, Latvia, Lithuania, Poland, Slovakia, and Slovenia - entered the European Union (EU). Later, in 2007, two additional countries - Bulgaria and Romania - joined them. In order to join the EU, these countries enacted banking reforms during the 1990s that decreased government intervention. At the same time, many of these banks adopted the laws, managerial practices, and indexing techniques of the German banking system. These changes, along with the closer relationship many global financial institutions developed with banks in centraleastern European countries, are thought to have improved the performance of banks in these central-eastern European countries (Weill, 2001), seven of which Bulgaria, Czech Republic, Hungary, Poland, Romania, Slovakia, and Slovenia are the subject of this particular study.

Since Weill (2004) appeared in mimeo form in 2001, there have been relatively few research studies of banking efficiency in central-eastern European countries. ${ }^{1}$ Nikiel and Opiela (2002) examine one transition economy, that of Poland, and conclude that cost efficiencies may be determined less by bank ownership foreign versus domestic - and more by customer type. Using a parametric

\footnotetext{
The concept of efficiency in banking in the academic literature generally consists of the relationship between costs and output. As such, studies such as Weill (2004), Karas, Schoors and Weill (2010), and others cited here estimate various cost functions for banking.
} 
approach to measuring banking efficiency, they find that foreign banks servicing foreign and business customers are more cost-efficient and less profit-efficient than other banks in Poland. Jemric and Vujcic (2002) use data envelopment analysis (DEA) to investigate banking efficiency in Croatia from 1995-2000. Confirming earlier studies, they conclude that foreign banks are more efficient than domestic banks, and that newer banks are more efficient than older banks. ${ }^{2}$ They also find that bank size does not necessarily determine bank efficiency, although labor, fixed assets and bad loans are all significantly related to bank efficiencies.

Drakos (2003) investigates how interest margins relate to banking efficiency in 11 central-eastern European countries during the 1993-99 period. He concludes that the ownership type and the presence of foreign competition influence banking efficiency in these countries. In fact, Drakos (2003) suggests that transition economies should adopt more effective policies for encouraging the entry of foreign banks into their financial markets. Hasan and Marton (2003) investigate cost and profit functions for banks in Hungary during the 1993-98 period, using a multiproduct translog functional form. Their findings support the conclusion that the entry of foreign banks improves both the cost and profit efficiencies of domestic banks. Fries and Taci (2005) use data on 289 banks from 15 postcommunist countries to find that banking systems in countries where foreignowned banks have greater shares of total assets have lower costs. They also find that cost reductions come early in transition and development, rather than later, and that private banks are more efficient than state-owned banks. Finally, among private banks, those with a majority foreign ownership stake are more efficient than those wherein domestic ownership predominates. ${ }^{3}$ Finally, Yildirim and Phillippatos (2007) estimate banking efficiency in 12 transition countries of central and Eastern Europe during the 1993-2000 period. They find that foreign banks are cost efficient, but profit inefficient. This research indicates that there are improvements in efficiency when foreign banks are present.

Using commercial banking data from the 17 central-eastern European countries in Table 1 for 2000-04, the period leading up to the EU accessions of 2004 and 2007, this study builds on the extant literature by estimating a three-output translog cost function to compare the cost structures of central-eastern European banks. Although the issue of efficiency has been previously examined, we provide the first

\footnotetext{
${ }^{2}$ Grigorian and Manole (2002) also use DEA, and find that technology brought to central and eastern European countries from advanced foreign banks provides efficiencies to domestic banks.

${ }^{3}$ Many of these results are supported by Fries, Neven, Seabright, and Taci (2006).
} 
Table 1. Accession and Non-Accession Countries.

\begin{tabular}{cc}
\hline Accession Countries & Non-Accession Countries \\
\hline Bulgaria* & Albania \\
Czech Republic & Armenia \\
Hungary & Belarus \\
Poland & Croatia \\
Romania* & Georgia \\
Slovakia & Kazakhstan \\
Slovenia & Kyrgyzstan \\
& Moldova \\
& Russia \\
& Ukraine
\end{tabular}

* denotes countries entering EU in 2007.

study to examine Allen Partial Elasticities to investigate differences in inputsubstitutability for accession and non-accession countries for each year in our data set. We find that banks in EU accession countries have different cost structures than those in non-accession countries, generally exhibiting greater inputssubstitution elasticities. It is particularly noteworthy that the greater substitutability between capital and labor in EU accession countries suggests that banking industry employment will be lower in those countries after EU accession. Bank deposits are also found to be substitutes for labor, reflecting the substantial impact of international competition and technological advancements in the industry. As a result of the increased inputs-substitution elasticities found in this study, preaccession preparation for banking industry changes, such as the employment effects mentioned here, may be necessary in some instances.

\section{TRANSLOG Cost Function}

In order to make comparisons between banks we estimate the widely-used flexible translog cost function. Our translog is a three-output three-input cost function with Totalcost as the dependent variable. The dependent variable is total cost (Totalcost). Using actual dollar values, Totalcost is the sum of all input costs (i.e., capital costs + labor costs + commission costs).

The three outputs are Loans, Investment, and commission fees (Commrev). Loans represents net loans, which are calculated by subtracting loan reserves from total loans. Total loans contain the sum of commercial loans, credit cards, real 
estate loans, and installment loans. Investment includes taxable securities, taxexempt securities, stocks, bonds, and other forms of investment. These represent income sources for the banks in the dataset. Commrev represents fees charged by banks for transactions-related services, such as buying/selling securities and real estate. Despite not being a major source of output for banks, this variable is included because such transactions may be labor intensive.

The three inputs included here are capital, labor, and deposits. These appear through their prices - the price of capital $\left(P_{K}\right)$, the price of labor $\left(P_{L}\right)$, and the price of deposits $\left(P_{D}\right)$, respectively. ${ }^{4}$ The first, $P_{K}$, consists of two parts - physical capital costs and financial (portfolio) financial costs. Physical capital costs include occupancy costs (building), equipment costs, and the physical capital reserve. Financial capital costs include dividends, interest payments, and so on. The price of capital is calculated by totaling the payment for capital and dividing this total by the quantity of capital. Next, $P_{L}$ is calculated by dividing the sum of wages by the number of employees. Data for this variable come from full-time employees, and is equal to average annual wages for full-time employees. Finally, $P_{D}$ is calculated by dividing interest payments on total deposits by the size of total deposits, where deposits include demand deposits, time deposits, and other types.

Given these variable definitions, our translog has the familiar functional form:

$$
\begin{gathered}
\operatorname{LnTC}=\alpha_{0}+\alpha_{1} \ln Y_{1}+\alpha_{2} \ln Y_{2}+\alpha_{3} \ln Y_{3}+\beta_{1} \ln P_{K}+\beta_{2} \ln P_{L}+\beta_{3} \ln P_{D}+ \\
1 / 2\left(\delta_{11} \ln Y_{1} \ln Y_{1}+\delta_{12} \ln Y_{1} \ln Y_{2}+\delta_{13} \ln Y_{1} \ln Y_{3}+\delta_{22} \ln Y_{2} \ln Y_{2}+\delta_{23} \ln Y_{2} \ln Y_{3}\right. \\
+\delta_{33} \ln Y_{3} \ln Y_{3}+1 / 2\left(\gamma_{11} \ln P_{K} \ln P_{K}+\gamma_{12} \ln P_{K} \ln P_{L}+\gamma_{13} \ln P_{K} \ln P_{D}\right. \\
\left.+\gamma_{22} \ln P_{L} \ln P_{L}+\gamma_{23} \ln P_{L} \ln P_{D}+\gamma_{33} \ln P_{D} \ln P_{D}\right)+\rho_{11} \ln Y_{1} \ln P_{K}+\rho_{12} \ln Y_{1} \ln P_{L} \\
+\rho_{13} \ln Y_{1} \ln P_{D}+\rho_{21} \ln Y_{2} \ln P_{K}+\rho_{22} \ln Y_{2} \ln P_{L}+\rho_{23} \ln Y_{2} \ln P_{D}+ \\
\rho_{31} \ln Y_{3} \ln P_{K}+\rho_{32} \ln Y_{3} \ln P_{L}+\rho_{33} \ln Y_{3} \ln P_{D}+\varepsilon .
\end{gathered}
$$

In equation (1), $\mathrm{Y}_{\mathrm{i}}$ expresses the $\mathrm{i}^{\text {th }}$ output defined as follows; $\mathrm{Y}_{1}$ (Loans), $\mathrm{Y}_{2}$ (Investment), $\mathrm{Y}_{3}$ (Commrev), and $P_{K}, P_{L}, P_{D}$, represent the input prices of capital, labor, and deposits, and $\alpha, \beta, \delta, \gamma$, and $\rho$ are parameters to be estimated. Finally, the condition of positive linear homogeneity in input prices is illustrated as follows:

$$
\sum \beta=1, \sum \gamma=0, \text { and } \sum \rho=0
$$

\footnotetext{
${ }^{4}$ The treatment of deposits as inputs follows the intermediation approach to banking first used by Sealey and Lindley (1977).
} 
We use Seemingly Unrelated Regression (SUR) to jointly estimate the cost function and the share equations; SUR produces efficient and unbiased estimators (Zellner, 1962; Berndt, 1991; Greene, 2008; Kennedy, 2008). The cost share equations are:

$$
\begin{gathered}
S_{1}=\beta_{1}+\gamma_{11} \ln P_{K}+\gamma_{12} \ln P_{L}+\gamma_{13} \ln P_{D}+\rho_{11} \ln Y_{1} \\
+\rho_{21} \ln Y_{2}+\rho_{31} \ln Y_{3}+e_{1} \\
S_{2}=\beta_{2}+\gamma_{21} \ln P_{K}+\gamma_{22} \ln P_{L}+\gamma_{23} \ln P_{D}+\rho_{12} \ln Y_{1}+\rho_{22} \ln Y_{2}+\rho_{32} \ln Y_{2}+e_{2} \\
S_{2}=\beta_{3}+\gamma_{31} \ln P_{K}+\gamma_{32} \ln P_{L}+\gamma_{33} \ln P_{D}+\rho_{13} \ln Y_{1}+\rho_{23} \ln Y_{2}+\rho_{33} \ln Y_{3}+e_{3}
\end{gathered}
$$

Given that the sum of the three share equations above equals 1 , the cost share equations are not linearly independent. This yields a singularity problem that requires omitting one of the share equations.

Given parameter estimates from the translog system, the Allen Partial Elasticities $(A P E)$ can be calculated. These express the elasticity of an input ratio with respect to another input ratio, and illustrate the relationship between the inputs. ${ }^{5}$ Given that there are three inputs in the model, there are six APE. These are:

$$
\begin{aligned}
& \theta_{11}=\left(\gamma_{11}+S_{1}\left(S_{1}-1\right)\right) / S_{1} \\
& \theta_{12}=\left(\gamma_{12}+S_{1} S_{2}\right) /\left(S_{1} S_{2}\right) \\
& \theta_{13}=\left(\gamma_{13}+S_{1} S_{3}\right) /\left(S_{1} S_{3}\right) \\
& \theta_{22}=\left(\gamma_{22}+S_{2}\left(S_{2}-1\right)\right) / S_{2} \\
& \theta_{23}=\left(\gamma_{23}+S_{2} S_{3}\right) /\left(S_{2} S_{3}\right)
\end{aligned}
$$

\footnotetext{
${ }^{5}$ Use of multi-product translog cost/profit functions and APE has been an important feature of the banking efficiency literature. For some seminal studies, see Humphrey (1981), Murray and White (1983), Mester (1987), Noulas, Ray, and Miller (1990), Hunter and Timme (1993), and Williams and Gardener (2003). For use of some of these concepts for other industries, such as electric power, see Berry and Mixon (1999).
} 


$$
\theta_{33}=\left(\gamma_{33}+S_{3}\left(S_{3}-1\right)\right) / S_{3}
$$

In equations (7)-(12), $\theta_{11}, \theta_{22}$, and $\theta_{33}$ are own $A P E, \theta_{12}, \theta_{13}$, and $\theta_{23}$ are cross $A P E, \mathrm{~S}_{1}$ is the cost share for capital, $\mathrm{S}_{2}$ is the cost share for labor, and $\mathrm{S}_{3}$ is the cost share for total deposits. ${ }^{6}$

\section{Data and Empirical Results}

The data used in this study are from BankScope, a database covering 25,000 banks around the world. The time frame examined is 2000-2004, the period leading up to accession by a portion of the accession countries grouping. Summary statistics for the three outputs for both accession countries and non-accession countries indicate that accession countries exhibit a larger average banking scale than is found in non-accession countries. ${ }^{7}$ On the cost share side, in 2000 the average cost share of capital, labor, and deposits for accession (non-accession) countries is 25 (37) percent, 16 (25) percent, and 59 (38) percent, respectively. This illustrates that the largest expense is interest costs, followed by capital costs. Statistics from the other years (2001-04), as well as from banking concerns in the individual countries, generally support those above.

Given that the variables enter the SUR system in logarithmic form, the parameter estimates are interpreted as elasticity estimates. Also, because total costs will rise when output rises and when input prices rise, the six parameters for the three outputs and three input prices (i.e., $\alpha_{1}, \alpha_{2}, \alpha_{3}, \beta_{1}, \beta_{2}$, and $\beta_{3}$ ) must be positive. According to the SUR results, which are too voluminous to be presented here, but are available upon request, all of these parameter estimates are indeed positive. Given that the variables enter the SUR system in logarithmic form, the parameter estimates are interpreted as elasticity estimates. As such, we turn our attention next to a discussion of the Allen Partial Elasticities, first for the accession countries and then for the non-accession countries.

As Tables 2 through 6 indicate, capital and labor are strong substitutes for

\footnotetext{
${ }^{6}$ It should be noted that there are three values for cost share: actual, mean, and fitted. For the purposes of this study, the mean value is utilized.

${ }^{7}$ Summary statistics for the outputs and the input prices are computed for the two groupings of countries - accession and non-accession - for each year in our panel (i.e., 2000-04). They are also computed for each country for each year. Thus, a large number of tables are produced. In an effort to keep the presentation here efficient, these are available from the authors upon request.
} 
Table 2. Allen Partial Elasticities of Substitution - 2000.

\begin{tabular}{clccccc}
\hline & \multicolumn{2}{c}{ Accession Countries } & \multicolumn{3}{c}{ Non-Accession Countries } \\
\hline & Capital & Labor & Deposits & Capital & Labor & Deposits \\
Capital & -0.349 & -5.571 & 0.734 & -0.559 & 1.453 & 1.605 \\
Labor & & 0.130 & 8.786 & & -0.743 & 0.074 \\
Deposits & & & -0.520 & & & -0.337 \\
\hline
\end{tabular}

Table 3. Allen Partial Elasticities of Substitution - 2001.

\begin{tabular}{ccccccc}
\hline & \multicolumn{3}{c}{ Accession Countries } & \multicolumn{3}{c}{ Non-Accession Countries } \\
\hline & Capital & Labor & Deposits & Capital & Labor & Deposits \\
Capital & -0.737 & 0.547 & 0.808 & -0.737 & 0.649 & 1.323 \\
Labor & & -1.447 & 5.607 & & -0.878 & 1.538 \\
Deposits & & & -1.044 & & & -0.255 \\
\hline
\end{tabular}

accession countries in all years, save for 2001. The largest APE is 4.573 in 2004, and the smallest APE is 0.547 in 2001. Our results indicate that in 2000, capital and labor are complements. This finding suggests a structural change in 20002001. During this period many foreign banks entered financial markets in several accession countries, bringing with them more advanced banking techniques. The new techniques and machinery required additional employees. We note that during this period both capital and labor increase significantly, suggesting a complementary relationship. After 2001, the cost structure stabilizes with capital and labor becoming substitutes.

For the accession countries, labor and deposits are substitutes during the entire 2000-2004 period of study. This result is unsurprising. Deposits are the basis of the production of investments and loans. More financial loan officers improve efficiency by reducing the probability of bad loans. The consequence is that fewer deposits are required for the same number of loans. The APE for labor and deposits in accession countries range from a high of 8.786 in 2000 to a low of 1.192 in 2003.

For the accession countries we find that capital and deposits are substitutes for the entire 2000-2004 period. The is less variation in these elasticity estimates as compared to the others and they also tend to be lower, indicating that capital and deposits are less substitutable than capital/labor or labor/deposits. The APE range from a low of 0.027 in 2003 to a high of 1.552 in 2002.

The APE for the non-accession countries indicate all inputs are substitutes over the entire period. For capital and labor, the APE range from a low of 0.649 in 2001 
Table 4. Allen Partial Elasticities of Substitution - 2002.

\begin{tabular}{ccccccc}
\hline & \multicolumn{3}{c}{ Accession Countries } & \multicolumn{2}{c}{ Non-Accession Countries } \\
\hline & Capital & Labor & Deposits & Capital & Labor & Deposits \\
Capital & -0.654 & 2.853 & 1.552 & -0.734 & 1.179 & 0.051 \\
Labor & & -0.465 & 1.922 & & -0.745 & 0.112 \\
Deposits & & & -1.350 & & & -1.269 \\
\hline
\end{tabular}

Table 5. Allen Partial Elasticities of Substitution - 2003.

\begin{tabular}{ccccccc}
\hline & \multicolumn{3}{c}{ Accession Countries } & \multicolumn{3}{c}{ Non-Accession Countries } \\
\hline & Capital & Labor & Deposits & Capital & Labor & Deposits \\
Capital & -0.911 & 2.118 & 0.027 & -0.688 & 1.111 & 0.815 \\
Labor & & -0.462 & 2.966 & & -0.882 & 0.009 \\
Deposits & & & -1.260 & & & -0.835 \\
\hline
\end{tabular}

Table 6. Allen Partial Elasticities of Substitution - 2004.

\begin{tabular}{ccccccc}
\hline & \multicolumn{3}{c}{ Accession Countries } & \multicolumn{2}{c}{ Non-Accession Countries } \\
\hline & Capital & Labor & Deposits & Capital & Labor & Deposits \\
Capital & -0.970 & 4.573 & 0.546 & -0.571 & 1.079 & 1.352 \\
Labor & & -2.758 & 1.192 & & -0.387 & 1.065 \\
Deposits & & & -1.519 & & & -0.980 \\
\hline
\end{tabular}

to a high of 1.453 in 2000 . For labor and deposits, the APE in the non-accession countries ranges from a low of 0.009 in 2004 to a high of 1.538 in 2001. For capital and deposits, the APE ranges from a low of 0.051 in 2002 to a high of 1.605 in 2000 .

A comparison of these substitution elasticities between accession and nonaccession countries is instructive. If we examine the 2001-2004 period, 2000 being a year of transition, nearly all of the important substitution elasticities are higher in the accession countries. Over this period, in the accession countries the average capital-labor substitution elasticity is 2.523 . During the same period the average value is a much lower 1.005 for the non-accession countries. For the accession countries, the labor-deposits elasticities average 2.922, while in non-accession countries the average elasticity estimate is much less at 0.681 . Considering these two elasticities for each of the four years between 2001 and 2004, the elasticity estimate is higher in the accession countries in seven of the eight possible cases. This is a strong indication of the effects of new technologies and additional competition on input substitutability in the accession countries. 


\section{Concluding Comments}

This study suggests that, leading up to the European Union accessions of 2004 and 2007, commercial banks in the accession countries of central-eastern Europe exhibited different cost structures than their counterparts in the non-accession countries of central-eastern Europe. Using a multiproduct translog cost function approach, we find that banks in accession countries generally display a stronger input substitutability across capital, labor and deposits than that displayed by banks in non-accession countries due to the additional competition caused by the entry of foreign banks into their financial markets and to advancements in banking services technology. Of course, these input substitutability changes likely generate negative employment shocks in commercial banking across accession countries, a consequence that is best dealt with through pre-EU accession preparation.

Received 16 December 2010, Revised 2 November 2011, Accepted 8 November 2011

\section{References}

Berndt, E.R. (1991), The practice of econometrics: Classic and contemporary, Reading, MA: Addison-Wesley.

Berry, D.M. and F.G. Mixon, Jr. (1999), "Multiproduct outputs and scale economies in electric power production: Some new estimates," Review of Industrial Organization, 15, 65-76.

Drakos, K. (2002), "The efficiency of the banking sector in central and eastern Europe," Russian and East European Trade and Finance, 38, 33-44.

Drakos, K. (2003), "Assessing the success of reform in transition banking 10 years later: An interest margins analysis," Journal of Policy Modeling, 25, 309-317.

Fries, S. and A. Taci. (2002), "Banking reform and development in transition economies," European Bank for Reconstruction and Development, working paper.

Fries, S. and A. Taci. (2005), "Cost efficiency of banks in transition: Evidence from 289 banks in 15 post-communist countries," Journal of Banking and Finance, 29, 55-81.

Fries, S., D.J. Neven, P. Seabright, and A. Taci. (2006), "Market entry, privatization and bank performance in transition," Economics of Transition, 14, 579-610.

Greene, W.H. (2008), Econometric analysis, Upper Saddle River, NJ: Prentice-Hall.

Grigorian, D. and V. Manole. (2002), "Determinants of commercial bank performance in transition: An application of data envelopment analysis," The World Bank.

Hasan, I. and K. Marton. (2003), "Development and efficiency of the banking sector in a transitional economy: Hungarian experience," Journal of Banking and Finance, 27, 2, 249-2, 271. 
Humphrey, D.B. (1981), "Intermediation and cost determinants of large bank liability composition," Journal of Banking and Finance, 5, 167-185.

Hunter, W.C. and S.G. Timme. (1993), "Core deposits and physical capital: Reexamination of bank scale economies and efficiency with quasi-fixed inputs," Federal Reserve Bank of Atlanta, working paper.

Jemric, I. and B. Vujcic. (2002), "Efficiency of banks in Croatia: A DEA approach," Comparative Economic Studies, 44, 169-193.

Karas, A., K. Schoors and L. Weill. (2010), “Are private banks more efficient that public banks? Evidence from Russia," Economics of Transition, 18, 209-244.

Kennedy, P. (2008), A guide to econometrics, Malden, MA: Blackwell Publishing.

Mester, L.J. (1987), “A multiproduct cost study of savings and loans," Journal of Finance 42, 423-445.

Nikiel, E.M. and T.P. Opiela. (2002), "Customer type and bank efficiency in Poland: Implications for emerging market banking," Contemporary Economic Policy, 20, 255-271.

Noulas, A.G., S.C. Ray, and S.M. Miller. (1990), "Returns to scale and input substitution for large U.S. banks," Journal of Money, Credit, and Banking, 22, 94-108.

Sealey, C.W. and J.T. Lindley. (1977), "Inputs, outputs and a theory of production and cost at depository financial institutions," Journal of Finance, 32, 1,251-1,266.

Weill, L. (2004), "Measuring cost efficiency in European banking: A comparison of frontier techniques," Journal of Productivity Analysis, 21, 133-152.

Williams, J. and E. Gardener. (2003), "The efficiency of European regional banking," Regional Studies, 37, 321-330.

Yildirim, H.S. and G.C. Phillippatos. (2007), "Efficiency of banks: Recent evidence from the transition economies of Europe, 1993-2000," European Journal of Finance, 13, 123-143.

Zellner, A. (1962), "An efficient method of estimating seemingly unrelated regressions and tests for aggregation bias," Journal of the American Statistical Association, 57, 348-368. 